\title{
Reproductive dynamics of Lycengraulis grossidens (Clupeiformes: Engraulidae) and Platanichthys platana (Clupeiformes: Clupeidae) in a subtropical coastal lagoon
}

\author{
C. A. Lopes ${ }^{a, b *}$, D. A. Reynalte-Tataje ${ }^{c}$ and A. P. O. Nuñer ${ }^{a, b}$ \\ aPrograma de Pós-graduação em Aquicultura, Departamento de Aquicultura, Centro de Ciências Agrárias, Universidade \\ Federal de Santa Catarina - UFSC, Rodovia Admar Gonzaga, 1346, Itacorubi, CEP 88034-001, Florianópolis, SC, Brazil

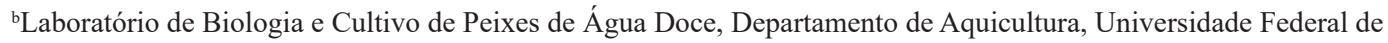 \\ Santa Catarina - UFSC, Rodovia Francisco Thomaz dos Santos, 3532, CEP 88066-260, Armação do Pântano do Sul, \\ Florianópolis, SC, Brazil \\ 'Universidade Federal da Fronteira Sul - UFFS, Campus Cerro Largo, Rua Jacob Haupenthal, 1580, Bloco A, \\ CEP 97900-000, Cerro Largo, RS, Brazil \\ *e-mail: eng.carolinalopes@hotmail.com
}

Received: October 4, 2016 - Accepted: April 10, 2017 - Distributed: October 31, 2018

(With 4 figures)

\begin{abstract}
We evaluated the reproductive dynamics of two fish species, Lycengraulis grossidens and Platanichthys platana, in a subtropical freshwater coastal lagoon (Peri Lagoon) in Brazil. Samples were collected from nine sites every two months from June 2008 to April 2012. Different fishing methods were used to capture larvae, juveniles, and adults. Limnological variables were obtained using multiparameter probe. More females than males were collected of both fish species and the chi-square test $\left(\chi^{2}\right)$ was used to confirm that the sex ratio was female-biased. Large numbers of maturing and mature fishes were observed in almost every sampling month. The gonadosomatic index (GSI) of L. grossidens was the highest in August, October, and December for females and in October for males, and no significant difference was found across years. The GSI of P. platana showed no significant difference across months for either sex; however, significant differences were recorded in year three (June 2010-April 2011) and year four (June 2011-April 2012) for females and in year three (June 2010-April 2011) for males. For both species, GSI was negatively correlated with temperature and water level. L. grossidens larvae were more abundant in October 2010, showing a positive correlation with water transparency, whereas P. platana larvae were more abundant in June 2011, showing a positive correlation with water transparency and negative correlation with temperature and precipitation. Both species were represented by different stages, including larvae, which confirm that these species reproduce in Peri Lagoon. Reproduction was more pronounced in autumn and winter; however, reproductive activity was evident throughout the sampling period. In conclusion, our results show that abiotic factors strongly influence the temporal pattern of reproductive activity and larval assemblages of both L. grossidens and P. platana in Peri Lagoon, Brazil.
\end{abstract}

Keywords: Clupeiformes, freshwater, ichthyoplankton, Peri Lagoon.

\section{Dinâmica reprodutiva de Lycengraulis grossidens (Clupeiformes: Engraulidae) e Platanichthys platana (Clupeiformes: Clupeidae) em uma lagoa costeira subtropical}

\begin{abstract}
Resumo
O objetivo do estudo foi avaliar a dinâmica reprodutiva de Lycengraulis grossidens e Platanichthys platana, na lagoa do Peri, uma lagoa costeira de água doce subtropical do Brasil. As amostras foram coletadas a cada dois meses, de junho/2008 a abril/2012 em nove pontos de amostragem. Para a captura de larvas, juvenis e adultos foram utilizados diferentes apetrechos de pesca. As variáveis limnológicas foram obtidas com sonda multiparâmetro. Estatisticamente, mais fêmeas do que machos foram capturadas para as duas espécies baseado no teste de qui-quadrado $\left(\chi^{2}\right)$. Grande número de peixes em maturação e maduros foram comuns em quase todos os meses de coleta. O índice gonadossomático (RGS) de L. grossidens variou significativamente apenas entre os meses, sendo mais elevada em agosto, outubro e dezembro para as fêmeas e em outubro para os machos; e não foram encontradas diferenças significativas entre os anos. Não foi encontrado diferença significativa para o RGS de P. platana entre os meses para cada sexo; entretanto, diferenças significativas foram obtidas para as fêmeas no ano três (junho 2010-abril 2011) e quatro (junho 2011-abril 2012) e no ano três (junho 2010-abril 2011) para os machos. Para as duas espécies, o RGS apresentou uma correlação negativa
\end{abstract}


com a temperatura e o nível de água. A distribuição das larvas apresentou variação temporal. As larvas de L. grossidens foram mais abundantes em outubro/2010, apresentando correlação positiva com a transparência da água. As larvas da espécie $P$. platana foram mais abundantes em junho/2011, apresentando correlação positiva com a transparência da água e negativa com a temperatura e a precipitação. A presença de L. grossidens e P. platana em diferentes estádios de maturação e a ocorrência de larvas confirmou que essas espécies se reproduzem na lagoa do Peri. O período reprodutivo foi mais pronunciado no outono e no inverno, porém a atividade reprodutiva ocorreu durante todo o período de coleta. Em conclusão, nossos resultados mostraram que os fatores abióticos influenciam fortemente o padrão temporal da atividade reprodutiva e a assembleia de larvas da L. grossidens e da P. platana na lagoa do Peri, Brasil.

Palavras-chave: Clupeiformes, água doce, ictioplâncton, lagoa do Peri.

\section{Introduction}

The order Clupeiformes includes fish commonly called anchovies, sardines, and herrings. This order is represented by seven families: Chirocentridae, Clupeidae, Denticipitidae, Dussumieriidae, Engraulidae, Pristigasteridae, and Sundasalangidae (Eschmeyer and Fong, 2017), and species are distributed in all continents (Malabarba et al., 2013) except Antarctica. Most species typically inhabit marine environments, but some inhabit estuarine or freshwater environments, such as rivers and freshwater coastal lagoons (Mello et al., 2011). These species play an important role in the food chain and are eaten by many local fauna (Cury et al., 2000). Some species have economic importance for the fishing industry (Vera-Alcaraz and Vuletich, 2016).

Clupeiformes include mostly small fish that inhabit shoals and swim near the water surface (Whitehead, 1985). In subtropical regions, the Engraulidae and Clupeidae families are very common in coastal lagoons (Barletta et al., 2010), such as Peri Lagoon in Brazil. This lagoon contains two species of Clupeiformes: Lycengraulis grossidens (Engraulidae) and Platanichthys platana (Clupeidae). L. grossidens occurs from Venezuela to Argentina, preferentially inhabiting shallow coastal waters up to $40 \mathrm{~m}$ in depth and of low salinity. It is a predatory species that feeds on zooplankton, crustaceans, and especially on small fish (Fischer et al., 2011). P. platana occurs from Brazil to Argentina and is abundant in some coastal lagoons of Brazil (Fialho et al., 2000); it feeds on zooplankton (Campello and Bemvenuti, 2002).

Studies of different species of Clupeiformes in different environments have shown that most species exhibit a seasonal reproductive period (Tsikliras et al., 2010). This reproductive period is influenced by the spatial and temporal variation of environmental factors. Water temperature, precipitation, $\mathrm{pH}$, electrical conductivity, and photoperiod are some of the abiotic factors that can trigger the onset of gonadal development and spawning (Baumgartner et al., 2008). Thus, spawning in optimal environmental conditions may maximize the survival of the offspring, ensuring maintenance of the local population.

Several studies have been conducted on L. grossidens and P. platana (Aguiaro et al., 2003; Mai et al., 2013, 2014; Nanini-Costa et al., 2016); however, no studies have examined the reproductive aspects of populations or evaluating the distribution of the larvae that inhabit Peri Lagoon, which is a protected area of the Santa Catarina
Island. Considering that Clupeiformes is one of the most abundant orders in lentic environments of coastal lagoons (Barletta et al., 2010), we expected that these species would be abundant and reproduce in Peri Lagoon. In addition, as temporal variations occur in large lagoons, we expected that the species would reproduce during a specific season. Therefore, this study aimed to evaluate spatial and temporal variations in population, the relative abundance of the two species, and the main events in the reproductive cycle of L. grossidens and P. platana in Peri Lagoon.

Our specific goals were to (I) determine the reproductive period of $L$. grossidens and P. platana, along with the spatial and temporal distribution of their larvae, in Peri Lagoon, to understand how these species use the lagoon; (II) analyze the relationship between their reproductive biology and larval population, to determine the effectiveness of reproduction; and (III) identify which limnological factors influence reproduction and larval survival. Our results provide new insights into the life-history characteristics of L. grossidens and P. platana in freshwater coastal lagoons.

\section{Material and Methods}

The study was conducted in Peri Lagoon, a coastal lagoon located in Santa Catarina State in southern Brazil (27 $41^{\prime} 28^{\prime \prime}$ ' and $27^{\circ} 45^{\prime} 38^{\prime \prime} \mathrm{S}$; $48^{\circ} 31^{\prime} 11^{\prime \prime}$ and $48^{\circ} 33^{\prime} 38^{\prime \prime} \mathrm{W}$ ), $3.0 \mathrm{~m}$ above sea level. The lagoon has a catchment area of approximately $20 \mathrm{Km}^{2}$ and is surrounded by the Atlantic Rainforest. The water surface area is approximately $5.2 \mathrm{Km}^{2}$, average depth is $4.0 \mathrm{~m}$, and maximum depth is $11.0 \mathrm{~m}$ (Santos et al., 1989). The volume of the lagoon is determined by rainfall (Teive et al., 2008) and by the draining of two streams (Cardoso et al., 2008). Surplus water runs through a 3.7-Km channel (Teive et al., 2008) that flows to the sea. The salinity of the lagoon is $0.0 \%$, because it is not directly affected by tidal fluctuation.

The present study was conducted from June 2008 to April 2012. This period was split into year one (June 2008-April 2009), year two (June 2009-April 2010), year three (June 2010-April 2011), and year four (June 2011-April 2012). Samples were collected every two months from nine sites, which were selected based on distinctive characteristics. Deep areas, dense vegetation, and stones were represented by sites one to five. Shallow areas, aquatic weeds (Scirpus californicus), and a sandy bottom were represented by sites six to nine (Figure 1). 


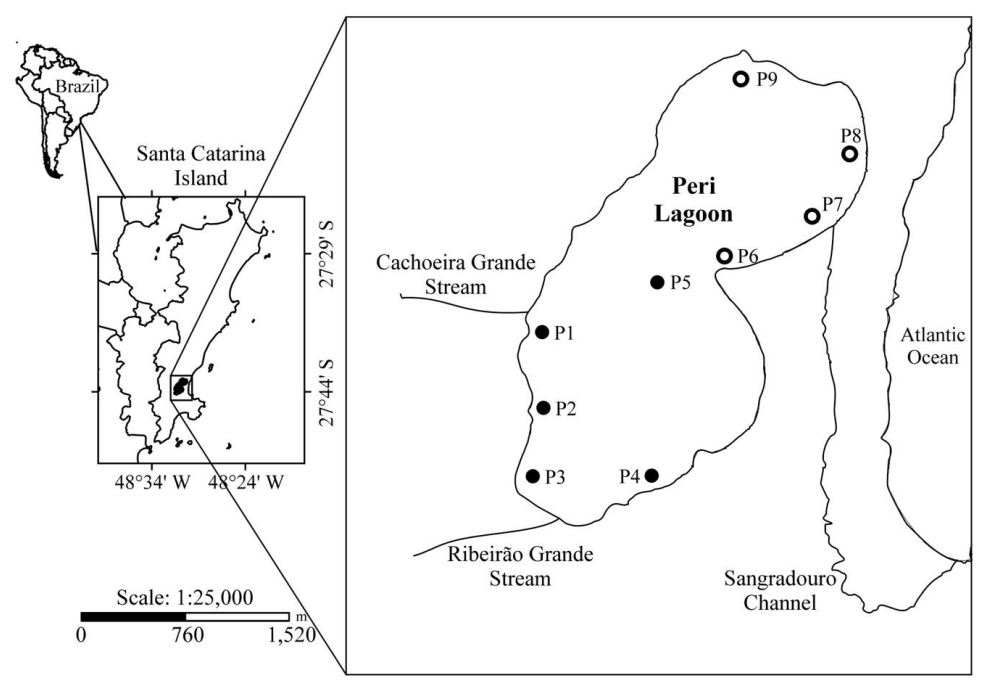

Figure 1. Map of the study area and sampling points in Peri Lagoon, Brazil, from June 2008 to April 2012. Closed circle $=$ environments with dense vegetation, deep areas, and stones. Open circle $=$ shallow areas with aquatic weeds (Scirpus californicus) and sandy bottom.

Fish were caught with gill nets $(12,15,20,25,30$, 40,50 , and $80 \mathrm{~mm}$ between adjacent knots; lengths of $20,30,40$, and $60 \mathrm{~m}$ ), distributed in coastal and pelagic environments. Cast nets, line nets, and seine nets were also used to capture fish of different sizes. Gill nets were set at dusk (18:00) and were kept in the water for $12 \mathrm{~h}$.

Captured fish were transported to the laboratory, where the total length $(\mathrm{mm})$ and weight $(\mathrm{g})$ of $L$. grossidens and $P$. platana were recorded. The maturation stages were macroscopically identified for each sex, and the weight (g) of the gonads was obtained using a precision scale $(0.001 \mathrm{~g})$. The maturation stages were macroscopically identified, according to Vazzoler (1996), as immature (I), maturing (M1), mature (M2), ovulating/sperm liberation (O-S), spent (S), regression (REG), and resting (RES).

Ichthyoplankton was collected at 21:00, with one replicate in a 24 -h interval, using cylindrical/conical nets (mesh size $500 \mu \mathrm{m})$ coupled with flowmeters (General Oceanics 3020R). The nets were dragged for $10 \mathrm{~min}$ on the water surface behind a moving boat. The collected material was stored in $500-\mathrm{mL}$ plastic bottles and fixed with $4.0 \%$ formalin. In the laboratory, the larvae were separated from the rest of the plankton under a stereomicroscope on a Bogorov plate. The larvae were counted and identified according to Whitehead (1985) and Farooqui et al. (2006). Larval abundance was standardized by a volume of $10 \mathrm{~m}^{3}$ (Nakatani et al., 2001).

Reproductive activity was analyzed based on the stages of maturity and the gonadosomatic index (GSI). The GSI expresses the percentage of gonad weight in relation to total fish weight. GSI was calculated according to the Equation 1 proposed by Vazzoler (1996):

$$
\mathrm{GSI}=100 \times[\mathrm{Wo} /(\mathrm{Wt}-\mathrm{Wo})]
$$

where Wo is the weight of the ovary and $\mathrm{Wt}$ is the total weight of the fish. Analysis of variance was used to analyze spatial and temporal variation in GSI and ichthyoplankton abundance, followed by Tukey's test when necessary. To analyze the spatial variation, the sample points were analyzed separately and grouped by environment (deep or shallow). Larval abundance was initially transformed to $\log (\mathrm{x}+1)$ to control extreme values.

Before removing the fishing nets, we measured the water temperature $\left({ }^{\circ} \mathrm{C}\right)$, dissolved oxygen concentration ( $\left.\mathrm{mg} \mathrm{L}^{-1}\right)$, electrical conductivity $\left(\mu \mathrm{S} \mathrm{cm}^{-1}\right)$, and $\mathrm{pH}$ with a multiparameter probe (WTW 350I). Water transparency (cm) was determined with a Secchi disk. These limnologic variables were measured with one replicate in a 24-h interval. Rainfall data $(\mathrm{mm})$ were obtained from the Santa Catarina Agricultural Research and Rural Extension Company. Data on lagoon water level were obtained from the State Company for Water and Sanitation. Climatological data used to determine periods of climatic events, such as El Niño and La Niña, were obtained from the National Oceanic and Atmospheric Administration (NOAA, 2016). The sex ratio was determined for month and year, and the chi-square test $\left(\chi^{2}\right)$ was used to determine whether it differed from the expected ratio of $1: 1$.

The Pearson correlation coefficient ( $\mathrm{r}$ ) was used to assess the degree of correlation among the GSI, the number of larvae, and the measured limnological variables. Except for $\mathrm{pH}$, all variables were $\log (\mathrm{x}+1)$ transformed.

\section{Results}

Overall, more females than males of both species were found. The length and weight of females and males were similar for $P$. platana, whereas $L$. grossidens females were larger than males (Table 1). 
The sex ratios of both species were significantly weighted toward females. In the case of $L$. grossidens $\left(\chi^{2}=39.2 ; \mathrm{df}=1 ; p<0.05\right)$, females and males represented $81 \%$ and $19 \%$ of individuals, respectively ( $4: 1$ ratio of females:males). The P. platana $\left(\chi^{2}=26.8 ; \mathrm{df}=1 ; p<0.05\right)$ population was $76 \%$ and $24 \%$ females and males, respectively (3:1 ratio; Table 2). The sex ratio of $L$. grossidens significantly differed across all months, and that of $P$. platana significantly differed in all months except February $\left(\chi^{2}=3.0 ; \mathrm{df}=1 ; p>0.05\right)$.

Maturing males and females of L. grossidens were found throughout the year; however, mature females were only found between August and December (Figures. 2A and 2B). Maturing males and females of P. platana were common in nearly all the sampled months, but were predominant in the summer (e.g., December-February). Mature males and females were predominant in April and August, respectively (Figures 2C and 2D).

The GSI of $L$. grossidens was higher in August, October, and December for females $(\mathrm{F}=18.1 ; p<0.05)$ and October for males $(\mathrm{F}=6.7 ; p<0.05)$; no significant difference was found across years $(p>0.05)$ (Figures $3 \mathrm{~A}$ and $3 \mathrm{~B}$ ). Across deep and shallow environments, the GSI of L. grossidens showed a significant difference only for females $(\mathrm{F}=7.8 ; p<0.05)$. The GSI of $P$. platana showed no significant difference across months or across deep and shallow environments for either sex $(p>0.05)$; however, significant difference were recorded in years three and four for females $(\mathrm{F}=7.5 ; p<0.05)$ and in year three for males $(\mathrm{F}=8.3 ; p<0.05)$ (Figures $3 \mathrm{C}$ and $3 \mathrm{D})$.

The mean values ( \pm standard deviation) of the limnological variables, rainfall, and water level are shown in Table 3. The mean water temperature markedly varied during June-August and October-April, whereas mean $\mathrm{pH}$ and electrical conductivity remained relatively stable throughout the entire study period. The mean concentration of dissolved oxygen was higher than $7.5 \mathrm{mg} \mathrm{L}^{-1}$ in all months and peaked in June and October. Water transparency was similar throughout the study, as was the mean monthly

Table 1. Number $(n)$ and mean ( \pm standard deviation) length and weight of females and males of Lycengraulis grossidens and Platanichthys platana captured in Peri Lagoon, south Brazil, from June 2008 to April 2012. Minimum-maximum values are presented within parentheses.

\begin{tabular}{cccccc}
\hline & \multicolumn{2}{c}{ L. grossidens } & & \multicolumn{2}{c}{ P. platana } \\
\cline { 2 - 3 } \cline { 5 - 6 } & Females & Males & & Females & Males \\
\hline$n$ & 427 & 99 & & 233 & \\
Length $(\mathrm{mm})$ & $167.6 \pm 24.1$ & $145.4 \pm 16.5$ & & $93.9 \pm 24.8$ & $90.9 \pm 19.7$ \\
& $(42-292)$ & $(110-190)$ & & $(51-144)$ & $(59-114)$ \\
Weight $(\mathrm{g})$ & $26.5 \pm 17.1$ & $16.3 \pm 11.5$ & & $7.3 \pm 1.7$ & $6.4 \pm 1.0$ \\
& $(5.0-193.8)$ & $(7.6-35.0)$ & & $(1.0-13.1)$ & $(1.3-11.0)$ \\
\hline
\end{tabular}

Table 2. Monthly and annual capture of female and male Lycengraulis grossidens and Platanichthys platana in Peri Lagoon, Brazil, from June 2008 to April 2012.

\begin{tabular}{|c|c|c|c|c|c|c|}
\hline & Period & Females & Males & Total & $\mathrm{F}: \mathrm{M}$ & $\chi^{2}$ \\
\hline \multirow[t]{10}{*}{ L. grossidens } & June & 118 & 10 & 128 & $11.8: 1$ & $40.8^{*}$ \\
\hline & August & 85 & 15 & 100 & $5.7: 1$ & $37.0 *$ \\
\hline & October & 59 & 13 & 72 & $4.5: 1$ & $14.4 *$ \\
\hline & December & 37 & 9 & 46 & 4.1:1 & $23.5^{*}$ \\
\hline & February & 60 & 27 & 87 & $2.2: 1$ & $71.2 *$ \\
\hline & April & 72 & 25 & 97 & 2.9:1 & $49.0^{*}$ \\
\hline & Year 1 & 107 & 23 & 130 & 4.7:1 & $41.8 *$ \\
\hline & Year 2 & 99 & 24 & 123 & 4.1:1 & $37.2 *$ \\
\hline & Year 3 & 114 & 15 & 129 & 7.6:1 & $58.9^{*}$ \\
\hline & Year 4 & 111 & 37 & 148 & $3: 1$ & $25.0^{*}$ \\
\hline \multirow[t]{10}{*}{ P. platana } & June & 39 & 13 & 52 & $3: 1$ & $25.0 *$ \\
\hline & August & 42 & 8 & 50 & $5.2: 1$ & $46.2^{*}$ \\
\hline & October & 49 & 10 & 59 & $4.9: 1$ & $43.7 *$ \\
\hline & December & 19 & 1 & 20 & $19: 1$ & $81.0 *$ \\
\hline & February & 27 & 19 & 46 & $1: 1$ & 3.0 \\
\hline & April & 57 & 23 & 80 & $2.4: 1$ & $18.1^{*}$ \\
\hline & Year 1 & 2 & 0 & 2 & - & $100.0 *$ \\
\hline & Year 2 & 20 & 3 & 23 & $6.7: 1$ & $54.6^{*}$ \\
\hline & Year 3 & 129 & 34 & 163 & $3.8: 1$ & $34.0^{*}$ \\
\hline & Year 4 & 82 & 37 & 119 & $2.2: 1$ & $14.3 *$ \\
\hline
\end{tabular}

$\mathrm{F}: \mathrm{M}=$ female:male ratio; $*$ = significant $(\alpha=0.05)$. 

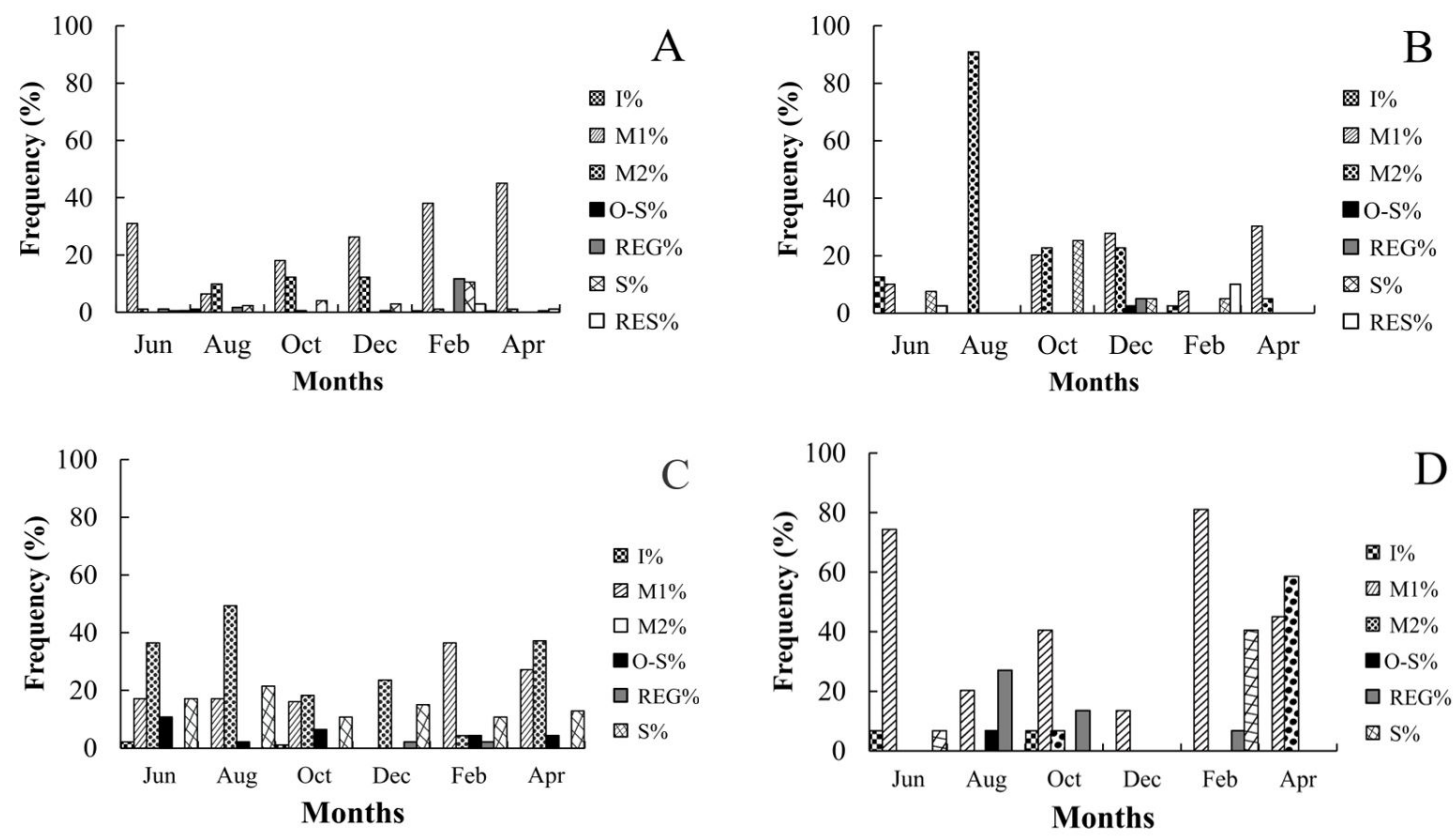

Figure 2. Maturity stages (\%) of females (A) and males (B) of Lycengraulis grossidens and females (C) and males (D) of Platanichthys platana in Peri Lagoon, Brazil, from June 2008 to April 2012. Immature (I); maturing (M1); mature (M2); ovulating/sperm liberation (O-S); regression (REG); spent (S); and resting (RES).

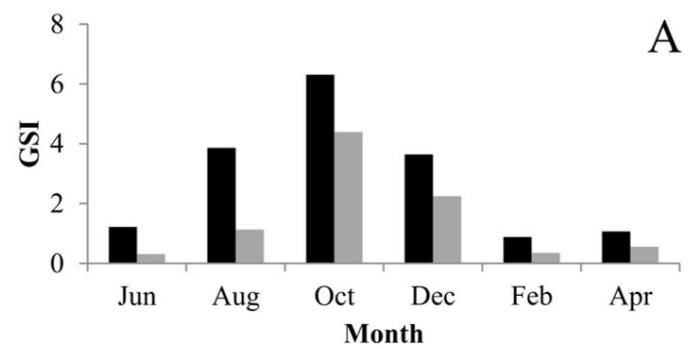

- Female Male

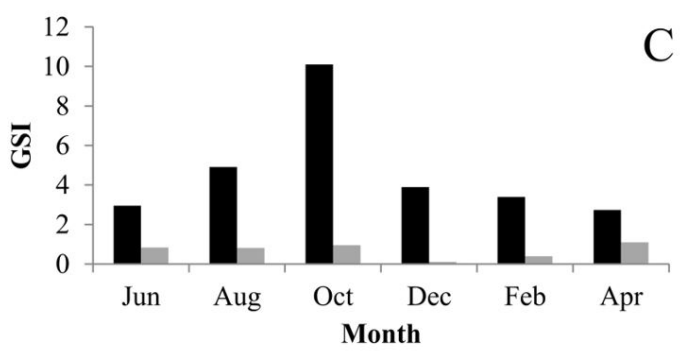

- Female Male

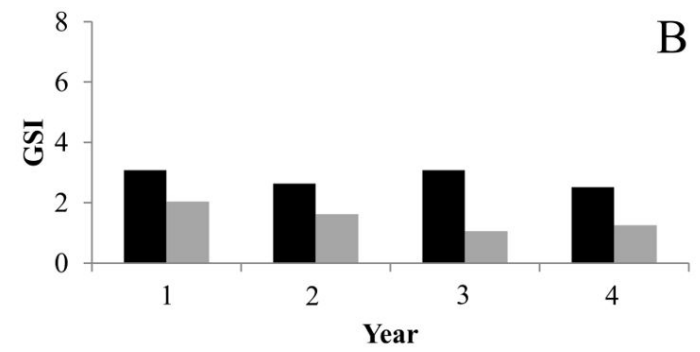

- Female Male

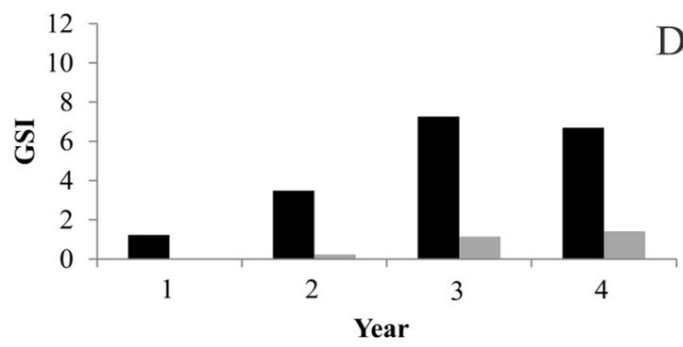

- Female $=$ Male

Figure 3. Monthly (A) and annual (B) distribution of the gonadosomatic index (GSI) of females and males of Lycengraulis grossidens and monthly (C) and annual (D) distribution of females and males of Platanichthys platana in Peri Lagoon, Brazil, from June 2008 to April 2012.

rainfall, except for June, when it was lower. Water level remained stable throughout the study period.

The GSI values of both species were negatively correlated with water temperature and positively correlated with dissolved oxygen concentration and water level, whereas the abundance of both species was positively correlated with water level. P. platana also showed a negative correlation with rainfall and water temperature (Table 4). 
The second year was influenced by a moderate El Niño effect, while years three and four were influenced by a moderate and weak La Niña, respectively. Rainfall directly influenced water level; the highest water level was recorded in year two $(275 \mathrm{~cm})$, after which the water level declined in years three $(264 \mathrm{~cm})$ and four $(270 \mathrm{~cm})$.

During the sampling period, 107 and 786 larvae of L. grossidens and P. platana were captured, respectively. There was no statistical difference in the spatial distribution of the sites or between deep and shallow environments with regard to larval abundance for either species $(p>0.05)$.
The highest abundance of $L$. grossidens occurred in October of year three $\left(\mathrm{F}=6.2 ; p<0.05 ; 1.6 \pm 0.07\right.$ larvae $10 \mathrm{~m}^{-3}$; Figure 4A). The highest density of $P$. platana larvae occurred in June of year four $\left(\mathrm{F}=3.2 ; p<0.05 ; 7.5 \pm 0.20\right.$ larvae $10 \mathrm{~m}^{-3}$; Figure 4B).

The abundance of L. grossidens larvae was positively correlated with $\mathrm{pH}(\mathrm{r}=0.42 ; p<0.05)$ and water transparency $(\mathrm{r}=0.50 ; p<0.05)$. The abundance of $P$. platana larvae was positively correlated with water transparency $(\mathrm{r}=0.42 ; p<0.05)$ and negatively correlated with water temperature $(\mathrm{r}=-0.56 ; p<0.05)$ and precipitation $(\mathrm{r}=-0.68 ; p<0.05)$ (Table 4).
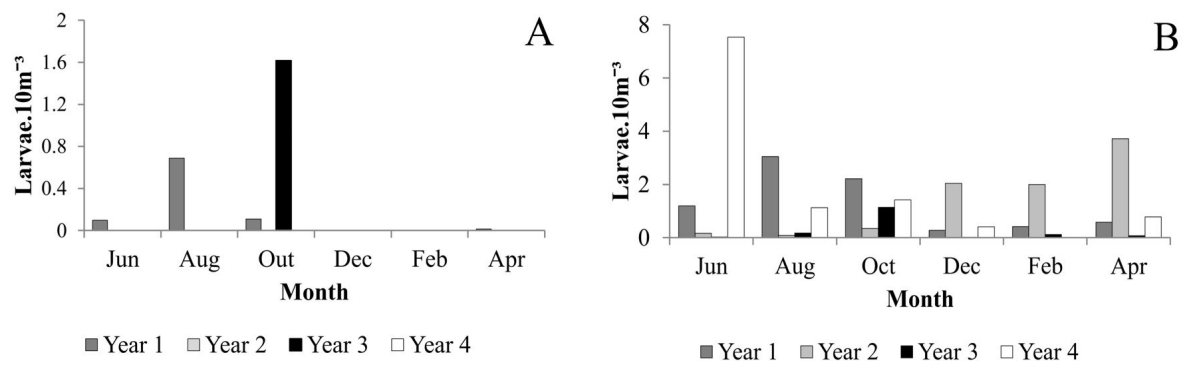

Figure 4. Monthly density of Lycengraulis grossidens (A) and Platanichthys platana (B) larvae in Peri Lagoon, Brazil, from June 2008 to April 2012.

Table 3. Limnological variables, rainfall, and water level (mean $\pm \mathrm{SD}$; minimum-maximum in parentheses) in Peri Lagoon, Brazil, from June 2008 to April 2012.

\begin{tabular}{|c|c|c|c|c|c|c|c|}
\hline Month & $\begin{array}{c}\text { Water } \\
\text { Temperature } \\
\left({ }^{\circ} \mathrm{C}\right) \\
\end{array}$ & pH & $\begin{array}{l}\text { Conductivity } \\
\qquad\left(\mu \mathrm{S} \mathrm{cm}^{-1}\right)\end{array}$ & $\begin{array}{c}\text { Dissolved } \\
\text { Oxygen } \\
\left(\mathrm{mg} \mathrm{L}^{-1}\right) \\
\end{array}$ & $\begin{array}{c}\text { Water } \\
\text { Transparency } \\
\text { (cm) } \\
\end{array}$ & $\begin{array}{c}\text { Rainfall } \\
(\mathrm{mm})\end{array}$ & $\begin{array}{c}\text { Water } \\
\text { Level }(\mathrm{cm})\end{array}$ \\
\hline June & $\begin{array}{l}18.3 \pm 0.6 \\
(17.1-19.2)\end{array}$ & $\begin{array}{l}6.3 \pm 1.0 \\
(4.0-7.7)\end{array}$ & $\begin{array}{l}54.3 \pm 25.0 \\
(10.9-75.2)\end{array}$ & $\begin{array}{c}8.4 \pm 1.7 \\
(5.4-11.7)\end{array}$ & $\begin{array}{l}116.1 \pm 19.7 \\
(80.0-150.0)\end{array}$ & $\begin{array}{c}2.5 \pm 5.5 \\
(0.0-32.2)\end{array}$ & $\begin{array}{c}277.1 \pm 12.1 \\
(260.0-306.5)\end{array}$ \\
\hline August & $\begin{array}{c}18.8 \pm 1.8 \\
(16.2-22.0)\end{array}$ & $\begin{array}{l}7.2 \pm 0.5 \\
(6.4-8.2)\end{array}$ & $\begin{array}{l}60.6 \pm 11.9 \\
(12.8-71.2)\end{array}$ & $\begin{array}{l}10.1 \pm 1.5 \\
(8.4-12.9)\end{array}$ & $\begin{array}{l}103.5 \pm 30.9 \\
(50.0-140.0)\end{array}$ & $\begin{array}{l}5.7 \pm 14.1 \\
(0.0-92.1)\end{array}$ & $\begin{array}{c}274.2 \pm 14.0 \\
(253.0-323.0)\end{array}$ \\
\hline October & $\begin{array}{c}21.4 \pm 1.3 \\
(19.7-23.6)\end{array}$ & $\begin{array}{l}7.7 \pm 0.5 \\
(6.8-8.4)\end{array}$ & $\begin{array}{c}69.1 \pm 6.0 \\
(62.1-77.0)\end{array}$ & $\begin{array}{c}8.3 \pm 2.8 \\
(3.3-10.5)\end{array}$ & $\begin{array}{c}123.5 \pm 18.0 \\
(110.0-160.0)\end{array}$ & $\begin{array}{c}5.2 \pm 9.2 \\
(0.0-45.9)\end{array}$ & $\begin{array}{c}279.2 \pm 10.1 \\
(261.0-300.0)\end{array}$ \\
\hline December & $\begin{array}{c}25.3 \pm 0.8 \\
(22.5-26.9)\end{array}$ & $\begin{array}{l}7.4 \pm 0.6 \\
(6.1-8.4)\end{array}$ & $\begin{array}{c}69.1 \pm 4.3 \\
(63.7-76.8)\end{array}$ & $\begin{array}{l}7.9 \pm 0.4 \\
(7.1-8.6)\end{array}$ & $\begin{array}{l}118.0 \pm 31.8 \\
(60.0-180.0)\end{array}$ & $\begin{array}{c}6.5 \pm 14.6 \\
(0.0-119.1)\end{array}$ & $\begin{array}{c}283.1 \pm 19.4 \\
(243.0-323.0)\end{array}$ \\
\hline Febru & $\begin{array}{c}28.8 \pm 1.0 \\
(26.5-30.2)\end{array}$ & $\begin{array}{l}7.4 \pm 0.6 \\
(6.8-8.5)\end{array}$ & $\begin{array}{c}65.4 \pm 2.1 \\
(62.5-68.6)\end{array}$ & $\begin{array}{l}7.9 \pm 0.8 \\
(6.5-8.8)\end{array}$ & $\begin{array}{l}118.1 \pm 23.6 \\
(90.0-150.0)\end{array}$ & $\begin{array}{l}5.8 \pm 11.2 \\
(0.0-59.3)\end{array}$ & $\begin{array}{c}270.2 \pm 20.7 \\
(231.5-303.0)\end{array}$ \\
\hline April & $\begin{array}{c}24.6 \pm 1.3 \\
(21.5-27.0)\end{array}$ & $\begin{array}{l}7.4 \pm 0.4 \\
(6.7-8.4)\end{array}$ & $\begin{array}{c}68.4 \pm 5.4 \\
(63.0-78.0)\end{array}$ & $\begin{array}{l}8.1 \pm 1.1 \\
(6.2-9.9)\end{array}$ & $\begin{array}{l}109.6 \pm 16.8 \\
(70.0-140.0)\end{array}$ & $\begin{array}{c}5.3 \pm 16.6 \\
(0.0-148.4)\end{array}$ & $\begin{array}{c}277.7 \pm 13.4 \\
(217.5-318.5)\end{array}$ \\
\hline
\end{tabular}

Table 4. Pearson correlation of gonadosomatic index (GSI) and larvae abundance $(n)$ for Lycengraulis grossidens and Platanichthys platana with respect to the limnological variables of Peri Lagoon, Brazil, from June 2008 to April 2012. Boldface values are significant $(p<0.05)$.

\begin{tabular}{lrrrrr}
\hline \multirow{2}{*}{ Variable } & \multicolumn{2}{c}{ L. grossidens } & & \multicolumn{2}{c}{ P. platana } \\
\cline { 2 - 3 } \cline { 5 - 6 } & GSI & $n$ & & GSI & $\mathbf{n}$ \\
\hline Water temperature $\left({ }^{\circ} \mathrm{C}\right)$ & $\mathbf{- 0 . 4 3}$ & -0.24 & & $\mathbf{- 0 . 5 6}$ & $\mathbf{- 0 . 5 6}$ \\
Dissolved oxygen $\left(\mathrm{mg} \mathrm{L}^{-1}\right)$ & $\mathbf{0 . 4 7}$ & 0.06 & $\mathbf{0 . 5 3}$ & 0.02 \\
$\mathrm{pH}$ & 0.38 & 0.42 & & 0.18 & -0.30 \\
Conductivity $\left(\mu \mathrm{S} \mathrm{cm}^{-1}\right)$ & 0.38 & 0.31 & 0.12 & -0.33 \\
Rainfall $(\mathrm{mm})$ & 0.28 & 0.04 & & 0.19 & $\mathbf{- 0 . 6 8}$ \\
Water transparency $(\mathrm{cm})$ & 0.08 & $\mathbf{0 . 5 0}$ & & -0.15 & $\mathbf{0 . 4 2}$ \\
Water level $(\mathrm{cm})$ & $\mathbf{0 . 4 3}$ & -0.11 & & $\mathbf{0 . 6 3}$ & -0.24 \\
\hline
\end{tabular}




\section{Discussion}

Our data showed that L. grossidens and P. platana have the ability to adjust their reproductive period in response to environmental conditions in Peri Lagoon. The final stages of maturation of both species occurred throughout the year, with spawning occurring in any season and location in the lagoon. Maturation also was recorded in all years of the study, even though different climatic conditions occurred during this period. Thus, our results showed that these species of Clupeiformes exhibit high reproductive plasticity, which is why they are able to maintain representative populations in that ecosystem.

In a previous study in the Custódias Lagoon (Rio Grande do Sul/Brazil), the breeding season of $P$. platana extended from early winter to early summer, peaking in October and November (Fialho et al., 2000). In the Peri Lagoon, the breeding season peaked in autumn and winter, even though maturing and mature fish were detected in all months. Fialho et al. (2000) suggested that the reproductive period of clupeids is longer in regions with low latitudes, and that the spawning period in these regions shows greater variability than in higher latitude regions, where reproduction depends on a shorter period of primary production. This pattern might not apply to L. grossidens and P. platana or to our study location because our results show that individuals were ready to spawn throughout the year in Peri Lagoon. The lagoon is located in a subtropical region, with well-defined seasons, at a higher latitude than that of Custódias Lagoon. In subtropical latitudes, clupeids reproduce throughout the year as they do in tropical regions (Wootton and Smith, 2014). The difference in the amplitude of the reproductive period between Custódias and Peri Lagoons might be related to differences in the environmental conditions of each ecosystem, such as temperature. For instance, environments with high latitudes, such as the Rio Grande do Sul, have lower average temperatures, which might stimulate a longer spawning period than that detected in Peri Lagoon. Furthermore, reproduction occurred when the photoperiod was decreasing, and as photoperiod and temperature are correlated, we conclude that temperature was the main trigger to fish reproduction. Another factor is that Peri Lagoon is located in a protected area with forest surrounding the lagoon that supplies the system with nutrients; therefore, the shallow areas facilitate high primary production for long periods. Nikolsky (1969) suggested that food supply is the most important factor influencing reproduction. For instance, oligotrophic aquatic environments predominantly support males and females with high GSI when food is abundant.

L. grossidens and P. platana dominate the ichthyofauna in Peri Lagoon (Ferreira et al., 2017). The average body length of the former species that we recorded was $167.6 \mathrm{~mm}$ for females and $145.4 \mathrm{~mm}$ for males, higher than that recorded by Goulart et al. (2007) for L. grossidens $(110 \mathrm{~mm})$ in the Middle Uruguay River region (Rio Grande do Sul/Brazil). The average body length of the latter species was $93.9 \mathrm{~mm}$ for females and $90.9 \mathrm{~mm}$ for males in the present study, compared with a maximum length of $80 \mathrm{~mm}$ for P. platana reported by Bruno et al. (2013) in a coastal lagoon in Argentina. The larger size recorded for both species in Peri Lagoon might be related to lower predation (i.e., few large predators) on adult animals (Sticca, 2013) or to high food availability. One interesting aspect of clupeids' biology is that they are able to adjust their growth rates to food supply. This phenomenon is well illustrated by Limnothrissa spp., which only grow to half the size in Kariba Lake that they do in the more nutrient-rich Kivu and Tanganyika Lakes (Marshall, 1984).

More females than males of both L. grossidens and P. platana species were present in Peri Lagoon. An unbalanced sex ratio is natural in fish populations (Tsikliras and Koutrakis, 2013). In a review, Tsikliras et al. (2010) stated that in $72 \%$ of studied fish stocks exhibit a female-biased sex ratio. Like other species, females tend to be more abundant that males in Clupeiformes (Tsikliras and Koutrakis, 2013). Studies in other environments have also shown a strong female bias in various Clupeiformes species (Fialho et al., 2000; Corrêa et al., 2005; Deshmukh et al., 2010). This bias could be explained by ecological factors (Gamble and Zarkower, 2012), environmental conditions, reproductive behavior, or food availability (Vandeputte et al., 2012). High female bias might also represent an adaptive strategy to boost egg numbers, resulting in more offspring being recruited (García-Abad et al., 1998).

The clupeiform females captured in our study were generally larger and heavier than the males. Because females invest more energy than males in reproduction, they tend to have a greater body weight and length (Jonsson and Jonsson, 2015). Size differences were also recorded for Anchoa januaria in Sepetiba Bay (southeastern Brazil), where females were larger than males (Santos et al., 2007). Larger females represent an advantage for the population, because they produce a larger quantity of high-quality gametes (Jonsson and Jonsson, 2015) that exhibit reduced vulnerability to predation (Helfman et al., 1987) and can better survive unfavorable periods (such as reduced food availability), due to the presence of larger energy stores.

Reproductive activity was detected at all sampling sites and environments for both species. In general, small pelagic clupeids are highly mobile, occupying various environments in different seasons (Alheit et al., 2012). The success of clupeids as pelagic fishes in Peri Lagoon might also be related to the fact that they are primarily planktivorous but are able to utilize other food if necessary, including organic detritus (Otobo, 1979), algae, and insects (Sticca, 2013).

Both L. grossidens and P. platana exhibited temporal reproductive plasticity, as shown by the presence of mature males and females in all seasons, especially autumn and winter, when the highest GSI values were recorded. However, the presence of mature adults does not mean that a species will spawn (Nakatani et al., 2001). In some situations, fish are ready to spawn; however, the environment does not offer optimal conditions, such as food and shelter, 
to ensure the development of offspring. In these cases, the vitellogenic oocytes are reabsorbed and the gonads regress (Jalabert, 2005). However, the presence of larvae in Peri Lagoon confirmed that both species experienced favorable spawning conditions and did successfully spawn. Furthermore, a parallel study in Peri Lagoon reported the larvae of both species were among the five most captured species (Ferreira et al., 2017).

Stable environments typically have a positive effect on specialist species, while environmental disturbances favor generalist species, which possess greater plasticity in breeding and feeding behavior (Vanderpham et al., 2013). A previous study in Peri Lagoon showed that $L$. grossidens is a specialist species, feeding on other fish, and is one of the major predators in the lagoon, along with Hoplias malabaricus and Centropomus parallelus (Sticca, 2013). When the supply of small forage fish increases, carnivorous fish benefit from this food resource and increase their population as well (Carpenter et al., 1985). Conversely, $P$. platana is an opportunistic species with high food plasticity. An analysis of the stomach contents of P. platana showed that it consumes different organisms in two coastal lagoons with different characteristics (Aguiaro et al., 2003), including microalgae, invertebrates, bivalves, chironomids, copepods, and cladocerans. In the Peri Lagoon, this species mostly consumes zooplankton (Sticca, 2013). This plasticity in diet might favor population growth in this species.

The positive correlation of GSI with water level in the lagoon suggests that a combination of environmental factors trigger reproductive activity for the two studied clupeiforms. For many Neotropical fish species, the reproductive period is associated with changes in water level (Duarte et al., 2007), which is considered one of the most important seasonal events in freshwater environments (Lowe-McConnell, 1999), along with temperature (Baumgartner et al., 2008). Lower temperature and a high water level seem to influence the gonadal development of both L. grossidens and P. platana in Peri Lagoon.

The abundance of $L$. grossidens larvae showed high temporal variability; however, ichthyoplankton of this species were only detected during June, August, and October. Thus, while mature adult fish occur year-round, spawning only occurs during the coldest season. Larval abundance was positively correlated with water transparency. Higher water transparency facilitates the detection of prey (Suzuki and Pompeu, 2016), which might favor L. grossidens larvae as they prey on zooplankton. The abundance of P. platana larvae was highest during the driest and coldest periods. These larvae may be the result of spawning events that occurred during the period that adults had a high GSI.

The high abundance of $L$. grossidens and P. platana in Peri Lagoon was linked to several factors, including a higher number of females and the large size of females. These factors might contribute to recruitment into the population and multiple spawning events over a protracted reproductive period. Reproduction in all environments in the lagoon and the production of large numbers of eggs and larvae also contribute to the species' abundance. Both species use the Peri Lagoon as the sole site to complete their life cycle, so unlike some other fish, they avoid the stress of migration and need not depend on floods for spawning. All of these factors help these two species enhance their populations in this lagoon.

\section{Conclusions}

The present study showed that $L$. grossidens and P. platana are opportunistic fish species with regard to their reproductive strategy in the Peri Lagoon. Our results showed that females were larger and more abundant than males and suggested that both species complete their life cycle in the lagoon, adjusting the breeding season to a period with optimal environmental conditions, typically during the autumn and winter. Low water levels and high water transparency seemed to favor and enhance the reproductive activity of these Clupeiformes. Our results provide new insights into how the reproductive biology of $L$. grossidens and P. platana enables them to thrive in a subtropical freshwater coastal lagoon.

\section{Acknowledgements}

The authors thank their colleagues from the Laboratory of Biology and Cultivation of Freshwater Fish (LAPAD/UFSC) for assisting with sampling and processing of the biological material and CAPES for providing the scholarship granted to C.A.L. This work was funded by the Fundação de Apoio à Pesquisa Científica e Tecnológica do Estado de Santa Catarina (FAPESC 4449/2010-0).

\section{References}

AGUIARO, T., BRANCO, C.W.C., VERANI, J.R. and CARAMASCHI, É.P., 2003. Diet of the Clupeid fish Platanichthys platana (Regan, 1917) in two different Brazilian coastal lagoons. Brazilian Archives of Biology and Technology, vol. 46, no. 2, pp. 215-222. http://dx.doi.org/10.1590/S1516-89132003000200013.

ALHEIT, J., POHLMANN, T., CASINI, M., GREVE, W., HINRICHS, R., MATHIS, M., O'DRISCOLL, K., VORBERG, R. and WAGNER, C., 2012. Climate variability drives anchovies and sardines into the North and Baltic Seas. Progress in Oceanography, vol. 96, no. 1, pp. 128-139. http://dx.doi.org/10.1016/j.pocean.2011.11.015.

BARLETTA, M., JAUREGUIZAR, A.J., BAIGUN, C., FONTOURA, N.F., AGOSTINHO, A.A., ALMEIDA-VAL, V.M.F., VAL, A.L., TORRES, R.A., JIMENES-SEGURA, L.F., GIARRIZZO, T., FABRÉ, N.N., BATISTA, V.S., LASSO, C., TAPHORN, D.C., COSTA, M.F., CHAVES, P.T., VIEIRA, J.P. and CORREA, M.F.M., 2010. Fish and aquatic habitat conservation on South America: a continental overview with emphasis on Neotropical systems. Journal of Fish Biology, vol. 76, no. 9, pp. 2118-2176. PMid:20557657. http://dx.doi.org/10.1111/j.1095-8649.2010.02684.x.

BAUMGARTNER, G., NAKATANI, K., GOMES, L.C., BIALETZKI, A., SANCHES, P.V. and MAKRAKIS, M.C., 2008. Fish larvae from the upper Paraná River: Do abiotic factors affect larval density? Neotropical Ichthyology, vol. 6, no. 4, pp. 551-558. http://dx.doi.org/10.1590/S1679-62252008000400002. 
BRUNO, D.O., BARBINI, S.A., ASTARLOA, J.M.D. and MARTOS, P., 2013. Fish abundance and distribution patterns related to environmental factors in a choked temperate coastal lagoon (Argentina). Brazilian Journal of Oceanography, vol. 61, no. 1, pp. 43-53. http://dx.doi.org/10.1590/S1679-87592013000100005.

CAMPELLO, F.D. and BEMVENUTI, M.A., 2002. Diferenciação morfométrica e osteológica entre Ramnogaster arcuata (Jenyns) e Platanichthys platana (Regan) (Teleostei, Clupeidae). Revista Brasileira de Zoologia, vol. 19, no. 3, pp. 757-766. http://dx.doi. org/10.1590/S0101-81752002000300013.

CARDOSO, F.S., PEREIRA, G., AGUDO-PADRÓN, A.I., NASCIMENTO, C. and ABDALLA, A., 20082017 [viewed 22 January 2017]. Análise do uso e ocupação da terra na bacia da Lagoa do Peri, Florianópolis (SC). Caminhos de Geografia [online], vol. 9, no. 27, pp. 201-213. Available from: http://www. seer.ufu.br/index.php/caminhosdegeografia/article/view/15750/8912

CARPENTER, S.R., KITCHELL, J.F. and HODGSON, J.R., 1985. Cascading trophic interactions and lake productivity: fish predation and herbivory can regulate lake ecosystems. Bioscience, vol. 35, no. 10, pp. 634-639. http://dx.doi.org/10.2307/1309989.

CORRÊA, E.D., CHAVES, P.T. and GUIMARÃES, P.R.B., 2005. Biology of Chirocentrodon bleekerianus (Poey, 1867) (Clupeiformes: Pristigasteridae) in a continental shelf region of southern Brazil. Brazilian Archives of Biology and Technology, vol. 48, no. 3, pp. 419-427. http://dx.doi.org/10.1590/S151689132005000300013 .

CURY, P., BAKUN, A., CRAWFORD, R.J.M., JARRE, A., QUIÑONES, R.A., SHANNON, L.J. and VERHEYE, H.M., 2000. Small pelagics in upwelling systems: patterns of interaction and structural changes in "wasp waist" ecosystems. ICES Journal of Marine Science, vol. 57, no. 3, pp. 603-618. http://dx.doi. org/10.1006/jmsc.2000.0712.

DESHMUKH, A.V., KOVALE, S.R., SAWANT, M.S., SHIRDNANKAR, M.M. and FUNDE, A.B., 2010. Reproductive biology of Sardinella longiceps along Ratnagiri coast off Maharashtra. Indian Journal of Marine Sciences, vol. 39, no. 2, pp. 274-279.

DUARTE, S., ARAÚJO, F.G., SALES, A. and BAZZOLI, N., 2007. Morphology of gonads, maturity and spawning season of Loricariichthys spixii (Siluriformes, Loricariidae) in a subtropical reservoir. Brazilian Archives of Biology and Technology, vol. 50, no. 6, pp. 1019-1032. http://dx.doi.org/10.1590/S151689132007000700013.

ESCHMEYER, W.N. and FONG, J.D., 2017 [viewed 22 January 2017]. Species by Family / Subfamily [online]. Available from: http://research.calacademy.org/research/ichthyology/catalog/ SpeciesByFamily.asp

FAROOQUI, T.M., DITTYE, J.G. and SHAW, R.F., 2006. Engraulidae: Anchovies. In: W.J. RICHARDS. Early stages of atlantic fishes: an identification guide for the Western Central North Atlantic. Florida: Taylor \& Francis Group, vol. 1, pp. 1333-1336.

FERREIRA, N.C., GUERESCHI, R.M., MACHADO, C., LOPES, C.A. and NUÑER, A.P.O., 2017. Structure and diversity of fishes in a freshwater and coastal subtropical lagoon. Journal of Fish Biology, vol. 90, no. 4, pp. 1265-1282. PMid:27859226. http:// dx.doi.org/10.1111/jfb.13226.

FIALHO, C.B., NUNES, D.M. and HARTZ, S.M., 2000. Biologia reprodutiva de Platanichthys platana (Regan, 1917) da lagoa das Custódias, Tramandaí, Rio Grande do Sul, Brasil (Clupeiformes: Clupeidae). Comun. Mus. Ciênc. Tecnol. PUCRS, Sér. Zool., vol. 13 , no. 2 , pp. $167-176$.
FISCHER, L.G., PEREIRA, L.E.D. and VIEIRA, J.P., 2011. Peixes estuarinos e costeiros. Rio Grande: Luciano Gomes Fischer. 131 p.

GAMBLE, T. and ZARKOWER, D., 2012. Sex determination. Current Biology, vol. 22, no. 8, pp. 275-262. PMid:22537624. http://dx.doi.org/10.1016/j.cub.2012.02.054.

GARCÍA-ABAD, M.C., YÁÑEZ-ARANCIBIA, A., SÁNCHESGIL, P. and TAPIA-GARCÍA, M., 1998. Distribución, abundancia y reproducción de Opisthonema oglinum (Pisces: Clupeidae) en la plataforma continental del sur del Golfo de México. Revista de Biología Tropical, vol. 46, no. 2, pp. 257-266.

GOULART, M.G., ASCHENBRENNER, A.C., BORTOLUZZI, T., SILVEIRA, C.R., LEPKOSKI, E.D., MARTINS, J.A., BRANDLI, E.S., ROOS, D.C., QUEROL, E. and QUEROL, M.V., 2007 [viewed 4 October 2016]. Análise do crescimento de escamas de Lycengraulis grossidens (Agassiz, 1829), em populações da bacia rio Uruguai médio, Rio Grande do Sul. Biodiversidade Pampeana [online], vol. 5, no. 1, pp. 3-8. Available from: http:// revistaseletronicas.pucrs.br/ojs/index.php/biodiversidadepampeana/ article/view/2603/2016

HELFMAN, G.S., FACEY, D.E., HALES, L.S.J. and BOZEMAN, E.L.J., 1987. Reproductive ecology of the American eel. In: M.J. DADSWELL, R.J. KLAUDA, C.M. MOFFITT, R.L. SAUNDERS, R.A. RULIFSON and J.E. COOPER, eds. Common strategies of anadromous and catadromous fishes. Bethesda: American Fisheries Society, vol. 1, pp. 42-56.

JALABERT, B., 2005. Particularities of reproduction and oogenesis in teleost fish compared to mammals. Reproduction, Nutrition, Development, vol. 45, no. 3, pp. 261-279. PMid:15982453. http:// dx.doi.org/10.1051/rnd:2005019.

JONSSON, B. and JONSSON, N., 2015. Sexual size dimorphism in anadromous brown trout Salmo trutta. Journal of Fish Biology, vol. 87 , no. 1, pp. 187-193. PMid:25959597. http://dx.doi. org/10.1111/jfb. 12704 .

LOWE-MCCONNELL, R.H., 1999. Estudos ecológicos de comunidades de peixes tropicais. São Paulo: EDUSP. 584 p.

MAI, A.C.G., CONDINI, M.V., ALBUQUERQUE, C.Q., LOEBMANN, D., SAINT'PIERRE, T.D., MIEKELEY, N. and VIEIRA, J.P., 2014. High plasticity in habitat use of Lycengraulis grossidens (Clupeiformes, Engraulididae). Estuarine, Coastal and Shelf Science, vol. 141, pp. 17-25. http://dx.doi.org/10.1016/j. ecss.2014.01.014.

MAI, A.C.G., VIEIRA, J.P., PLAVAN, A.A., NOBREGA, M.F., MORAES, L.E., RODRIGUES, F.L. and MARINS, L.F., 2013. Isolation and characterization of 18 microsatellites for Lycengraulis grossidens (Pisces: Clupeiformes. Conservation Genetics Resources, vol. 5, no. 1, pp. 15-18. http://dx.doi.org/10.1007/ s12686-012-9718-2.

MALABARBA, L.R., NETO, P.C., BERTACO, V. A., CARVALHO, T.P., SANTOS, J.F. and ARTIOLI, L.G.S., 2013. guia de identificação dos peixes da Bacia do Rio Tramandaí. Porto Alegre: Via Sapiens. 140 p.

MARSHALL, B.E., 1984. Small pelagic fishes and fisheries in African inland waters: espèces de petits pélagiques et leurs pêcheries dans les eaux intérieures de l'Afrique. Rome: FAO. 25 p. CIFA Tech.Pap. Doc. Tech. CPCA, vol. 14.

MELLO, F.T., GONZÁLEZ-BERGONZONI, I. and LOUREIRO, M., 2011. Peces de agua dulce del Uruguay. Uruguay: PPRMGAP. 188 p. 
NAKATANI, K., AGOSTINHO, Â.A., BAUMGARTNER, G., BIALETZKI, A., MAKRAKIS, M.C. and PAVANELLI, C.S.,2001. Ovos e larvas de peixes de água doce: desenvolvimento e manual de identificação. Maringá: EDUEM. 377 p.

NANINI-COSTA, M.H., QUINÁGLIA, G.A., HELD, B., PETESSE, M.L. and ESTEVES, K.E., 2016. Bioacumulação de mercúrio total em Platanichthys platana (Regan, 1917), um peixe zooplanctívoro invasor no complexo Billings (Alto Tietê, SP). Boletim do Instituto de Pesca, vol. 42, no. 3, pp. 674-690. http:// dx.doi.org/10.20950/1678-2305.2016v42n3p674.

NATIONAL WEATHER SERVICE - NOAA, 2016 [viewed 4 October 2016]. Cold \& warm episodes by season [online]. Available from: http://www.cpc.noaa.gov/products/analysis_monitoring/ ensostuff/ensoyears.shtml

NIKOLSKY, G.V., 1969. Theory of fish population dynamics. Edinburgh: Oliver and Boyd. 323 p.

OTOBO, F.O., 1979. The fish fauna changes and the place of clupeids in Lake Kainji, Nigeria. Hydrobiologia, vol. 64, no. 2, pp. 99-103. http://dx.doi.org/10.1007/BF00023185.

SANTOS, G.F., SILVA, J.T., MENDONÇA, M. and VEADO, R.W., 1989. Análise ambiental da Lagoa do Peri. Geosul, vol. 8, pp. 101-123.

SANTOS, J.N.S.,ARAÚJO, F.G., SILVA, M.A. and VASCONCELLOS, R.M., 2007. Sex ratio and sexual dimorphism of the anchovy Anchoa januaria (Actinopterygii, Engraulidae) in a tropical bay in south-eastern Brazil. Journal of Fish Biology, vol. 71, no. 3, pp. 877-888. http://dx.doi.org/10.1111/j.1095-8649.2007.01562.x.

STICCA, S.C., 2013 [viewed 4 October 2016]. Organização trófica da assembleia de peixes de uma lagoa costeira subtropical, Santa Catarina, Brasil [online]. Florianópolis: Universidade Federal de Santa Catarina, 45 p. Dissertação de Mestrado em Ecologia. Available from: https://repositorio.ufsc.br/handle/123456789/107298

SUZUKI, F.M. and POMPEU, P.S., 2016. Influence of abiotic factors on ichthyoplankton occurrence in stretches with and without dams in the upper Grande River basin, south-eastern
Brazil. Fisheries Management and Ecology, vol. 23, no. 2, pp. 99-108. http://dx.doi.org/10.1111/fme.12159.

TEIVE, L.F., LISBOA, L.K. and PETRUCIO, M.M., 2008. Uma revisão da disponibilidade de dados ecológicos visando o direcionamento de novas pesquisas na Lagoa do Peri. Biotemas, vol. 21 , no. 2 , pp. 133-143. http://dx.doi.org/10.5007/2175$7925.2008 \mathrm{v} 21 \mathrm{n} 2 \mathrm{p} 133$.

TSIKLIRAS, A.S., ANTONOPOULOU, E. and STERGIOU, K.I., 2010. Spawning period of Mediterranean marine fishes. Reviews in Fish Biology and Fisheries, vol. 20, no. 4, pp. 499-538. http:// dx.doi.org/10.1007/s11160-010-9158-6.

TSIKLIRAS, A.C. and KOUTRAKIS, E.T., 2013. Growth and reproduction of European sardine, Sardina pilchardus (Pisces: Clupeidae), in northeastern Mediterranean. Cahiers de Biologie Marine, vol. 54, pp. 365-374.

VANDEPUTTE, M., QUILLET, E. and CHATAIN, B., 2012. Are sex ratios in wild European sea bass (Dicentrarchus labrax) populations biased? Aquatic Living Resources, vol. 25, no. 1, pp. 77-81. http://dx.doi.org/10.1051/alr/2012002.

VANDERPHAM, J.P., NAKAGAWA, S. and CLOSS, G.P., 2013. Feeding ability of a fluvial habitat-specialist and habitat-generalist fish in turbulent and still conditions. Ecology Freshwater Fish, vol. 22, no. 4, pp. 596-606. http://dx.doi.org/10.1111/eff.12064.

VAZZOLER, A.E.A. M., 1996. Biologia da reprodução de peixes teleósteos: teoria e prática. Maringá: EDUEM. 167 p.

VERA-ALCARAZ, H. and VULETICH, E.J.D., 2016. Records of clupeiform fishes from Paraguay. Ichthyological Contributions of Peces Criollos, vol. 46, pp. 1-6.

WHITEHEAD, P.J.P., 1985. Clupeoid fishes of the world (Suborder Clupeoidei): part 1. Rome: FAO Fisheries Synopsis. 303 p. FAO Species Catalogue, vol. 7.

WOOTTON, R.J. and SMITH, C., 2014. Reproductive biology of teleost fishes. New Jersey: Wiley-Blackwell. 496 p. 